\title{
PRODUCTION, PHYSICOCHEMICAL QUALITY AND ANTIOXIDANT CAPACITY OF 'NIAGARA ROSADA' GRAPE GRAFTED ON DIFFERENT ROOTSTOCKS
}

\author{
PRODUÇÃO, QUALIDADE FÍSICO-QUIMMICA E CAPACIDADE ANTIOXIDANTE \\ DA UVA 'NIAGARA ROSADA' SOBRE DIFERENTES PORTA-ENXERTOS
}

\begin{abstract}
Bruna Thais Ferracioli VEDOATO ${ }^{1}$; Francisco José DOMINGUES NETO ${ }^{1}$; Adilson PIMENTEL JUNIOR ${ }^{\mathbf{1}}$; Ana Paula Maia PAIVA ${ }^{\mathbf{1}}$; Marlon Jocimar Rodrigues da SILVA ${ }^{\mathbf{1}}$; Mara Fernandes MOURA ${ }^{2}$; Giuseppina Pace Pereira LIMA ${ }^{3}$; Marco Antonio TECCHIO ${ }^{1}$

1. São Paulo State University - UNESP, School of Agriculture, Plant Production Department, Botucatu, SP, Brazil; 2. Agronomic Institute of Campinas - IAC, Fruit Center Jundiaí, SP, Brazil; 3. São Paulo State University, Institute of Biosciences, Botucatu, SP, Brazil.
\end{abstract}

\begin{abstract}
The objective of this study is to evaluate the effect of rootstocks on grape production, quality and antioxidant capacity of 'Niagara Rosada' grape in two productive cycles. The work was developed in Jundiaí-SP, Brazil $\left(26^{\circ} 06^{\prime} \mathrm{S}, 46^{\circ} 55^{\prime} \mathrm{W}\right.$ and an average altitude of $\left.745 \mathrm{~m}\right)$. The experimental design was in randomized blocks with subdivided plots, the plots being represented by the rootstocks and the subplots by the production cycles, with four replications, each consisting of 6 plants. The treatments consisted of a combination of 'IAC 313 Tropical', 'IAC 572 Jales', 'IAC 571-6 Jundiaí', 'IAC 766 Campinas' and '106-8 Mgt' as rootstocks and 'Niagara Rosada' as graft, and the production cycles were 2013 and 2014. The number of bunches, production and productivity of the vines, the physical characteristics of bunches, berries and stalks and the physicochemical composition of the must (soluble solids content, titratable acidity, $\mathrm{pH}$ and the relation soluble solids/titratable acidity) were evaluated in production cycles of 2013 and 2014). The content of chlorophylls, anthocyanins, carotenoids, flavonoids and total phenolic compounds and the antioxidant activity of grapes were also evaluated in grape berries. The rootstocks did not influence the production and physical quality of 'Niagara Rosada' grapes. As for the chemical characteristics, rootstocks only had an effect on solids content, and 'IAC 766' and '106-8 Mgt' rootstocks promoted higher values of this characteristic. Likewise, the total phenolic compounds and the antioxidant activity of the grapes were not influenced by the studied rootstocks. The vines in 2013 presented higher production and better physical characteristics of the grapes, however, the soluble solids content in this cycle was lower than in 2014.
\end{abstract}

KEYWORDS: Antioxidant activity. Phenolic compounds. Table grape. Vitis labrusca.

\section{INTRODUCTION}

The 'Niagara Rosada' (Vitis labrusca $x$ V. vinifera) is a somatic mutation of the white Niagara identified in the city of Jundiaí, State of São Paulo, in a commercial vineyard in the year 1933 (SOUZA; MARTINS, 2002). Since then it has become the main common grape for table grown in the country, present in $98 \%$ of the Brazilian winegrowing properties, due to its ease of management in the cultivation by the producers and its sensorial and visual acceptance by the consumers (VERDI et al., 2011).

The success in the production of table grapes in superior quantity and quality is dependent on several factors in the handling, from the formation of the vineyard until the harvest. The use of rootstocks has become a mandatory practice in commercial grapevine plantations, mainly because it provides resistance to root phytopathogens, adaptation to different types of soil and an increase in productive performance of grapevines and qualitative grapes (MARGUERIT et al., 2012; DESOUKY et al., 2015; JIN et al., 2016; IBACACHE; ALBORNOZ; ZURITA-SILVA; 2016).

The grape is considered a major source of phenolic compounds when compared to other fruits and vegetables, but there is a great diversity of cultivars, resulting in grapes with different characteristics (ABE et al., 2007; POZZAN; BRAGA; SALIBE; 2012). In grapes and their byproducts, the phenolic compounds are directly related to sensory characteristics, such as color and taste. In addition, many beneficial health effects have been attributed to these compounds, such as antioxidants, anti-inflammatories, antimicrobials 
and anti-carcinogens (DÁVALOS; LASUNCIÓN, 2009).

The main commercial rootstocks were obtained, basically, through crosses between three species, such as Vitis berlandieri, Vitis riparia or Vitis rupestres, and in tropical regions with the species Vitis caribaea. Currently, the most rootstocks grown in Brazil are that developed by the genetic improvement program of IAC, as 'IAC 313', 'IAC 572, 'IAC 766', among others (MAIA; CAMARGO, 2012; SILVA et al., 2019). Grape rootstocks have their own ability to synthesize biochemical constituents that influence directly or indirectly various physical, physiological and biochemical properties of berries (SATISHA; RAMTEKE; KARIBASAPPA; 2007). Although there is limited information on the biochemical interactions between canopy and rootstocks in table grapes, many studies have reported the positive impacts of different rootstocks on grapes quality (REBELLO et al., 2013; SILVA et al., 2017). However, ideal rootstocks can contribute to food security, increasing production potential, creating new products with improved quality (ALBACETE et al., 2015).

Therefore, the purpose of this work was to evaluate the influence of rootstocks on grape production, on the physical-chemical quality and antioxidant capacity of 'Niagara Rosada' grape in two productive cycles.

\section{MATERIAL AND METHODS}

The experiment was carried out at the APTA Fruit Center of the Agronomic Institute of Campinas (IAC) in Jundiaí, eastern region of the State of São Paulo, Brazil (26 $06^{\circ}$ S, $46^{\circ} 55^{\prime} \mathrm{W}$ and an average altitude of $745 \mathrm{~m}$ ). The climate of the region, according to the Köppen classification is of the Cwa type, with an annual rainfall of $1.400 \mathrm{~mm}$, annual average temperature of $19.5^{\circ} \mathrm{C}$ and relative air humidity of $70.6 \%$. The soil of the experimental area was classified as Red Cambisolo Distrophic (EMBRAPA, 1999). The data of temperature and rainfall in the experimental area from August to December 2013 and 2014 are shown in Figure 1.
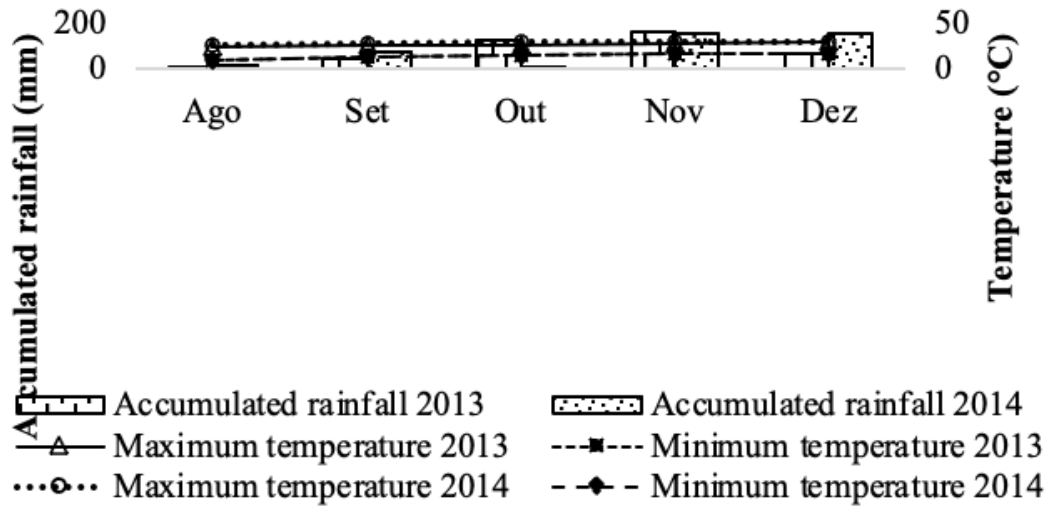

Figure 1. Temperature and rain index in the experimental area from August/2013 and December/2014 ate the APTA Fruit Center of the IAC, (CIIAGRO).

The 'Niagara Rosada' (Vitis labrusca x Vitis vinifera) was used in the sixth and seventh year of production, with the vines spaced at $2.0 \times 1.0 \mathrm{~m}$ and sustained in a low-drop system, with the wires located at $1.0 ; 1.3$ and $1.6 \mathrm{~m}$ above ground level.

The experimental design was in randomized blocks with subdivided plots, the plots being represented by the rootstocks and the subplots by the production cycles, with four replications, each consisting of 6 plants. The rootstocks that composed the treatments were: 'IAC 313 Tropical', 'IAC 572 Jales', 'IAC 571-6 Jundiaí', 'IAC 766 Campinas' and '106-8 Mgt', and the production cycles were 2013 and 2014.

In August 2013 and 2014 was made the prune of production with a yolk, and afterwards hydrogen cyanamide was applied at $5 \%$, aiming the induction and uniformity of sprouting. After bud emergence, when the branches were 10 to $15 \mathrm{~cm}$ in length, only one productive branch per yolk was selected. Other cultural practices, such as fertilization, control of weeds, pests and diseases were carried out according to the techniques used in the growing region.

The grapes were harvested by monitoring the soluble solids content and titratable acidity. When these stabilized, the harvest was performed, which, in the first cycle, occurred at 128 days after pruning (DAP) and in the second cycle at 127 DAP.

In both production cycles, the number of bunches per plant was evaluated by counting all bunches harvested. For the production, the total 
fresh mass of all the bunches of each experimental plot was obtained, being the value obtained divided by the number of plants, determining the average production per plant, expressed in kg per plant.

For productivity, the average production per plant was multiplied by the number of plants per hectare (5.000 plants), the result being expressed in $t$ $\mathrm{ha}^{-1}$. In a sample of 10 bunches per experimental plot, the fresh mass of the bunches (MFC) and the stump (MFE) were evaluated using a precision analytical balance $(0.1 \mathrm{~g})$, expressed in $\mathrm{g}$; the length and width of the bunches and the stump were obtained with the aid of a graduated ruler, expressed in $\mathrm{cm}$; the number of berries per bunch was obtained by dividing the berries total fresh mass in the bunch by the average fresh mass of 10 berries. Afterwards, 10 berries per sample were collected, totalizing 100 berries per plot, for determination of the fresh mass (MFB), length (CB) and berries width (LB), being the mass obtained in analytical balance, expressed in $\mathrm{g}$; and the dimensions, with the aid of ruler graduated in $\mathrm{mm}$.

The 100 berries sampled per plot for the physical characteristics were divided into two lots of 50 berries, one batch for the physicochemical analysis of the must and another batch for the biochemical analysis of the berries. The wort to determine the physicochemical composition was obtained by pressing the berries and the soluble solids (SS) contents were determined by direct refractometry through an Atago ${ }^{\circledR}$ digital refractometer, with automatic temperature compensation and the results expressed in ${ }^{\circ}$ Brix; Titratable acidity (TA) determined by titration with a standard solution of sodium hydroxide in $0.1 \mathrm{~N}$, having phenolphthalein as an indicator until the color-turning point, the results, being expressed as $\%$ of tartaric acid; by means of SS and AT values, the SS/AT relation was determined; and $\mathrm{pH}$ : using Micronal pHmeter B-274.

For the biochemical analyzes, the berries were immediately frozen in liquid nitrogen and then manually macerated in a porcelain mortar using a piston and stored at $-20^{\circ} \mathrm{C}$ until the analysis. Samples consisted in the use of the whole berry, being skin, pulp and seed. The contents of chlorophylls $a, b$ and total, anthocyanins and carotenoids were determined by the method proposed by Sims; Gamon (2002). The content of total polyphenols was determined using the FolinCiocalteau reagent (SINGLETON; ROSSI, 1965). The content of total flavonoids was determined according to the method described by Popova et al. (2004), with adaptations, and the antioxidant activity by the DPPH method was determined according to the methodology of Brand-Williams, Cuvelier and Berset (1995), modified by Rosetto et al. (2009). These analyzes were performed in triplicate.

The data were submitted to analysis of variance (test F) and the means compared by the Tukey test, at $5 \%$ probability. The component analysis (PCA) was conducted using XLSTAT statistical software, version 19.4 (Addinsoft, NY, USA), and applied to all data collected for 23 variables analyzed from 'Niagara Rosada' grafted on five rootstocks.

\section{RESULTS AND DISCUSSION}

There was no significant interaction between the rootstocks and the productive cycles in all evaluated characteristics of the 'Niagara Rosada' vine and grape, thus, the effect of these factors was analyzed in isolation.

Analyzing the isolated effect of the productive characteristics, it was verified that the highest production and productivity were found in the cycle of 2013, with $2.12 \mathrm{~kg}$ per plant and $10.60 \mathrm{t}$ $\mathrm{ha}^{-1}$, respectively (Table 1). There was no significant difference between the rootstocks evaluated for production and productivity of 'Niagara Rosada', with average yield ranging from 7.78 to $10.68 \mathrm{t} \mathrm{ha}^{-1}$. These values were lower than those obtained by Tecchio et al. (2011), in Votuporanga, Northwest of the State of São Paulo, which were obtained for the same grape, grafted on 'IAC 766' and 'IAC 571-6' rootstocks, average yields of 28.8 and $19.6 \mathrm{t} \mathrm{ha}^{-1}$, respectively. This difference can be justified by the different driving systems used in the experiments, considering that, in Votuporanga, the authors used the pergola system, while in the present study the vines were conducted on a trellis.

In the eastern region of the State of São Paulo, Tecchio et al. (2014) verified that 'Niagara Rosada' grape grafted on 'IAC 572' rootstock presented higher productivity in relation to 'IAC 313' rootstock. Mota et al. (2009) also observed that the 'IAC 572' rootstock provided higher productivity to 'Niagara Rosada' when compared to '106-8 Mgt' (Riparia do Traviú), 'IAC 313' and 'IAC 766' rootstocks, with medium values of 25.5; 23.8; 19.0 and $16.2 \mathrm{t} \mathrm{ha}^{-1}$, respectively. These variations may occur as a function of the different interactions that can occur between canopy and rootstock cultivation and through the interaction between these factors and the soil in each site studied. 
Table 1. The number of bunches, production and productivity of the 'Niagara Rosada' grape grafted on different rootstocks in two productive cycles. Jundiaí-SP, 2013 and 2014.

\begin{tabular}{lccc}
\hline Rootstocks & $\begin{array}{c}\text { Production } \\
\text { (kg per plant) }\end{array}$ & $\begin{array}{c}\text { Productivity } \\
\left(\mathrm{t} \mathrm{ha}^{-1}\right)\end{array}$ & Bunches per plant \\
\hline IAC 313 & 2.14 & 10.68 & 12.24 \\
IAC 572 & 1.56 & 7.78 & 9.61 \\
IAC 571-6 & 2.04 & 10.20 & 10.61 \\
IAC 766 & 1.70 & 8.48 & 11.00 \\
106-8 Mgt & 1.86 & 9.30 & 10.58 \\
\hline Productive cycle & & & \\
\hline 2013 & $2.12 \mathrm{a}$ & $10.60 \mathrm{a}$ & 10.30 \\
2014 & $1.59 \mathrm{~b}$ & $8.00 \mathrm{~b}$ & 15.90 \\
\hline CV 1 (\%) & 29.10 & 29.10 & 23.50 \\
CV 2 (\%) & 23.40 & 23.40 &
\end{tabular}

Means within columns followed by different litters differ significantly by Tuckey’s test $(p \leq 0.05)$.

There was no significant effect of the rootstocks on the number of bunches per plant of the 'Niagara Rosada' grapevine, which ranged from 9.61 to 12.24 in vines grafted on 'IAC 572 ' and 'IAC 313' rootstocks, respectively (Table 1). Similar results were found by Alvarenga et al. (2002), who observed that there was no difference in the numbers of 'Niagara Rosada' grapes grafted on 'IAC 766', 'IAC 572', 'IAC 313' and '106-8 Mgt' rootstocks in southern Minas Gerais. However, the average number of clusters per plant found by these authors with these rootstocks (15.28) was higher than the one found in our study (10.80).

The rootstocks did not influence the fresh mass, length and width of the clusters of cultivar Niagara Rosada, obtaining average values of $221 \mathrm{~g}$, $11.9 \mathrm{~cm}$ and $7.2 \mathrm{~cm}$, respectively (Table 2). Similarly, there was no effect of rootstocks on the number of berries per cluster and fresh mass, length and width of stalks. The values of fresh mass of bunches found in the present work are similar to those obtained by Terra et al. (2003), in Monte Alegre do Sul-SP, where the authors also did not obtain a significant difference in the fresh mass of 'Niagara Rosada' grapes on 'IAC 572', 'IAC 313', '106-8 Mgt' and 'IAC 766', with an average of 230 g.

Despite the higher values of bunches length found in the 2013 cycle, there was no significant difference between the productive cycles in width and in fresh mass of the 'Niagara Rosada' grapes, which certainly occurred due to the higher number of berries per cluster found in the 2014 cycle (Table 2 ). In this cycle were also found higher values of fresh mass, length and width of stalks.

Table 2. Fresh mass (FM), length (LEN) and width (WID) of the bunch, number of berries per bunch and fresh mass (FM), length (LEN) and width (WID) of the stem of the 'Niagara Rosada' grape grafted on different rootstocks in two productive cycles. Jundiaí-SP, 2013 and 2014.

\begin{tabular}{lccccccc}
\hline Rootstocks & $\begin{array}{c}\text { FM bunch } \\
(\mathrm{g})\end{array}$ & $\begin{array}{c}\text { LEN bunch } \\
(\mathrm{cm})\end{array}$ & $\begin{array}{c}\text { WID } \\
\text { bunch }(\mathrm{cm})\end{array}$ & $\begin{array}{c}\mathrm{N}^{\text {o }} \text { berry/ } \\
\text { bunch }\end{array}$ & $\begin{array}{c}\text { FM stem } \\
(\mathrm{g})\end{array}$ & $\begin{array}{c}\text { LEN stem } \\
(\mathrm{cm})\end{array}$ & $\begin{array}{c}\text { WID } \\
\text { stem }(\mathrm{cm})\end{array}$ \\
\hline IAC 313 & 220.0 & 11.4 & 6.9 & 59.8 & 5.6 & 8.3 & 4.7 \\
IAC 572 & 218.0 & 12.2 & 7.3 & 62.1 & 5.6 & 8.7 & 5.0 \\
IAC 571-6 & 234.0 & 12.2 & 7.3 & 66.0 & 5.9 & 7.9 & 5.1 \\
IAC 766 & 225.0 & 11.9 & 7.3 & 63.1 & 5.8 & 8.4 & 4.6 \\
106-8 Mgt & 210.0 & 11.8 & 6.9 & 59.3 & 5.1 & 8.9 & 4.7 \\
\hline Productive cycle & & & & & & & \\
\hline 2013 & 250.0 & $12.8 \mathrm{a}$ & 7.6 & $52.4 \mathrm{~b}$ & $7.1 \mathrm{a}$ & $8.8 \mathrm{a}$ & $5.0 \mathrm{a}$ \\
2014 & 190.0 & $10.9 \mathrm{~b}$ & 6.6 & $71.7 \mathrm{a}$ & $4.1 \mathrm{~b}$ & $8.1 \mathrm{~b}$ & $4.6 \mathrm{~b}$ \\
\hline CV 1 (\%) & 18.6 & 7.2 & 4.4 & 12.4 & 17.0 & 10.1 & 9.4 \\
CV 2 (\%) & 19.4 & 4.2 & 5.7 & 8.3 & 8.9 & 11.8 & 9.1 \\
\hline
\end{tabular}

Means within columns followed by different litters differ significantly by Tuckey’s test $(p \leq 0.05)$.

There was no significant effect of the rootstocks on the fresh mass, length and width of 'Niagara Rosada' grapes, with averages of $3.6 \mathrm{~g}$,
$20.6 \mathrm{~mm}$ and $18.4 \mathrm{~mm}$, respectively (Table 3 ). The average value of fresh berries in the present study was lower than those found by Mota et al. (2009) 
IAC 572 and IAC 766, with a value of 4.9, which was obtained from the 'Niagara Rosada' grapevine grafted on 'IAC 313', 'Ripária do Traviú', and 'IAC 572'. 4.6; 4.5 and $4.2 \mathrm{~g}$ per berry, respectively. Values higher than those of the present study were also obtained by Pauletto et al. (2001) that obtained fresh mass of the 'Niagara Rosada' berries grafted on the rootstock 'IAC 766' of $4.44 \mathrm{~g}$. The values obtained by these authors are similar to those found in the present work in the productive cycle of 2014, in which the values of fresh mass, length and width of berries were higher than the ones of 2013 .

Table 3. Fresh mass (FM), length (LEN) e width (WID) of the berries, soluble solids (SS), pH, titratable acidity (AT) and soluble solid relation/titratable acidity (SS/AT) of the 'Niagara Rosada' grape grafted on different rootstocks in two productive cycles. Jundiaí-SP, 2013 and 2014.

\begin{tabular}{lccccccc}
\hline Rootstocks & $\begin{array}{c}\text { FM } \\
\text { berry }(\mathrm{g})\end{array}$ & $\begin{array}{c}\text { LEN } \\
\text { berry }(\mathrm{mm})\end{array}$ & $\begin{array}{c}\text { WID } \\
\text { berry }(\mathrm{mm})\end{array}$ & SS ( ${ }^{\circ}$ Brix $)$ & pH & AT (\%) & SS/AT \\
\hline IAC 313 & 3.7 & 21.0 & 18.5 & $16.1 \mathrm{~b}$ & 3.31 & 0.39 & 44.8 \\
IAC 572 & 3.6 & 20.8 & 18.4 & $16.9 \mathrm{ab}$ & 3.35 & 0.43 & 42.3 \\
IAC 571-6 & 3.6 & 20.5 & 18.4 & $17.1 \mathrm{ab}$ & 3.33 & 0.44 & 42.5 \\
IAC 766 & 3.7 & 20.7 & 18.5 & $17.3 \mathrm{a}$ & 3.27 & 0.40 & 45.8 \\
106-8 Mgt & 3.6 & 20.5 & 18.3 & $17.3 \mathrm{a}$ & 3.29 & 0.40 & 44.6 \\
\hline Productive cycle & & & & & & & \\
\hline 2013 & $4.6 \mathrm{a}$ & $21.4 \mathrm{a}$ & $19.1 \mathrm{a}$ & $16.7 \mathrm{~b}$ & $3.43 \mathrm{a}$ & $0.32 \mathrm{~b}$ & $53.5 \mathrm{a}$ \\
2014 & $2.6 \mathrm{~b}$ & $20.0 \mathrm{~b}$ & $17.7 \mathrm{~b}$ & $17.2 \mathrm{a}$ & $3.19 \mathrm{~b}$ & $0.51 \mathrm{a}$ & $34.5 \mathrm{~b}$ \\
\hline CV 1 (\%) & 4.7 & 2.6 & 2.1 & 4.40 & 1.74 & 8.10 & 9.70 \\
CV 2 (\%) & 4.9 & 2.6 & 2.3 & 4.10 & 1.98 & 17.10 & 14.20 \\
\hline
\end{tabular}

Means within columns followed by different litters differ significantly by Tuckey’s test $(p \leq 0.05)$.

Evaluating the chemical characteristics of the must, it was verified a significant effect of rootstocks only on soluble solids content (SS), with the highest values obtained when 'Niagara Rosada' was grafted on rootstocks 'IAC 766 ' and ' $106-8$ Mgt', both with average values of $17.3^{\circ}$ Brix, however, differing significantly only from the combination of 'Niagara Rosada' with the 'IAC 313' rootstock, which obtained a SS content of 16.1 ${ }^{\circ}$ Brix. Every scion-rootstock combination in both evaluated cycles produced grapes with the minimum soluble solids content of $14.0^{\circ}$ Brix, established by Brazilian regulations for grape pulp (BRASIL, 2018). For titratable acidity (AT), $\mathrm{pH}$ and SS/AT ratio of 'Niagara Rosada' grape there was no significant difference between rootstocks (Table 3). The grapes produced in the 2013 cycle had higher $\mathrm{pH}$ and SS/AT values, while those produced in the 2014 cycle presented higher values of AT and SS. Alvarenga et al. (2002) observed the effect of 'IAC 766', 'IAC 572', 'IAC 313' and 'Riparia do Traviú' rootstocks on $\mathrm{pH}$ and titratable acidity of 'Niagara Rosada' grape, with higher $\mathrm{pH}$ value (3.33) and lower acid value (44.5 meq $\left.\mathrm{L}^{-1}\right)$ provided by 'Riparia do Traviú' and 'IAC 572' rootstocks, respectively, with avarage $\mathrm{pH}$ values similar to those obtained in the present study. The authors concluded that the rootstocks that provided lower $\mathrm{pH}$ were the ones that provided the crown with the highest yields.
In an experiment carried out in Caldas-MG, Mota et al. (2009), did not obtain a significant effect of the 'IAC 766', 'IAC 572', 'IAC 313' and '106-8 Mgt' rootstocks on the 'Niagara Rosada' grapes SS/AT ratio, however, titratable acidity values were obtained on the '106-8 Mgt' and 'IAC 572' rootstocks, and the highest soluble solids content was obtained when the vine was grafted onto ' $106-8$ Mgt' and 'IAC 766' rootstocks', with an average of $15.2^{\circ}$ Brix, lower values than those obtained in the present study in all evaluated rootstocks. The authors stated that because it is a grape consumed in natura, factors such as the balance between sugar and acidity and the coloring of the berries are quality differentials for 'Niagara Rosada'.

Pauletto et al. (2001) evaluated the soluble solids content of the 'Niagara Rosada' grape, and found few differences throughout the harvests evaluated, however, in the general average, the authors observed that fruits harvested from vines grafted on 'Kober 5BB' rootstocks and 'Schwarzmann' presented higher soluble solids contents than those obtained on 'IAC 313'. The effect of rootstocks on the chemical composition of grapes may be related to factors such as vigor, water and nutrient absorption capacity, resistance to diseases and interaction with the canopy (TECCHIO et al., 2014). Thus, this effect may directly influence the primary and secondary metabolites of the plants and, consequently, the quality of the grapes (DIAS et al., 2012; LEE; STEENWERTH, 2013). 
There was no significant effect of rootstocks on total chlorophyll content, total anthocyanins, total carotenoids, total flavonoids, total polyphenols and antioxidant activity of the 'Niagara Rosada' grape. When analyzing the effect of the productive cycles, a significant difference was observed only in total flavonoid contents, and the highest content of this compound $\left(4.06 \mathrm{mg} 100 \mathrm{~g}^{-1}\right)$ was obtained in the 2013 cycle (Table 4$)$.

Table 4. Chlorophyll (Clor), anthocyanins (Ant), carotenoids (Car), flavonoids (Flav) and total polyphenols (Pol) and antioxidant activity (AA) of the 'Niagara Rosada' grape grafted on different rootstocks in two productive cycles. Jundiaí-SP, 2013 and 2014.

\begin{tabular}{|c|c|c|c|c|c|c|}
\hline Rootstocks & Clor $\underset{1}{\mu} \mathrm{g} 100 \mathrm{~g}^{-}$ & Ant $\left(\underset{1}{\mu \mathrm{g} 100 \mathrm{~g}^{-}}\right.$ & Car $\left(\underset{1}{\mu g} 100 g^{-}\right.$ & $\begin{array}{c}\text { Flav } \\
\left(\mathrm{mgl00g}^{-1}\right)\end{array}$ & 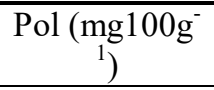 & $\begin{array}{c}\mathrm{AA} \\
\left(\mu \mathrm{g} \mathrm{g}^{-1}\right)\end{array}$ \\
\hline IAC 313 & 207.93 & 679.0 & 176.0 & 3.47 & 456.0 & 5337.0 \\
\hline IAC 572 & 254.88 & 639.0 & 184.0 & 3.34 & 472.0 & 4525.0 \\
\hline IAC 571-6 & 211.46 & 720.0 & 192.0 & 3.96 & 461.0 & 5360.0 \\
\hline IAC 766 & 283.79 & 651.0 & 193.0 & 3.78 & 483.0 & 5646.0 \\
\hline $106-8 \mathrm{Mgt}$ & 277.68 & 762.0 & 197.0 & 3.83 & 507.0 & 5325.0 \\
\hline \multicolumn{7}{|c|}{ Productive cycle } \\
\hline 2013 & 243.09 & 743.0 & 186.0 & $4.06 \mathrm{a}$ & 489.0 & 4977.0 \\
\hline 2014 & 211.19 & 636.0 & 190.0 & $3.29 \mathrm{~b}$ & 462.0 & 5500.0 \\
\hline CV $1(\%)$ & 26.37 & 26.30 & 18.20 & 26.10 & 20.90 & 34.70 \\
\hline CV $2(\%)$ & 20.14 & 28.30 & 16.90 & 19.90 & 25.70 & 28.90 \\
\hline
\end{tabular}

Means within columns followed by different litters differ significantly by Tuckey's test $(\mathrm{p} \leq 0.05)$.

The average value obtained for total chlorophyll of the 'Niagara Rosada' grape was $247.15 \mu \mathrm{g} 100 \mathrm{~g}^{-1}$. According to Volp, Renhe and Stringueta (2009), chlorophyll is not a chemically isolated molecule because it comprises a family of substances similar to each other, called chlorophyll $\mathrm{a}, \mathrm{b}, \mathrm{c}$ and $\mathrm{d}$. The most abundant and most important of this family is chlorophyll a, corresponding to 75 $\%$ of the green pigments found in plants. Several factors may be related to the presence and content of these pigments in the grape. The synthesis and concentration of chlorophyll in grape berry is induced by exposure of the bunch to the sun, in the absence of light, the synthesis of chlorophyll is reduced (DOWNEY; HARVEY, ROBINSON, 2004). Thus, the chlorophyll content in the grape may vary according to the characteristics of each cultivar, the environmental conditions of the vineyard and the management practices of the grapevines (KAMFFER; BRINDON; OBERHOLSTER; 2010). Phenolic compounds are one of the main responsible for the antioxidant activity of fruits and vegetables. The concentration of these compounds may vary depending on many factors, such as the species, the cultural practices adopted in the vineyard and the climatic conditions of the region (SILVA et al., 2019).

The average anthocyanin content found in the 'Niagara Rosada' grape on the different rootstocks was $689 \mu \mathrm{g} 100 \mathrm{~g}^{-1}$. In Caldas-MG, higher content of total anthocyanins was obtained in the same grape production, however, in vines grafted on rootstocks 'IAC 766', '106-8 Mgt', 'IAC 572 ' and 'IAC 313', average values were, respectively, $0.50 ; 0.48 ; 0.42$ and $0.39 \mathrm{mg} \mathrm{g}^{-1}$ of skin (MOTA et al., 2009). Several factors may influence the content of this pigment in grapes, including the species, variety, maturation stage, climatic conditions of the growing site (MUÑOZ-ESPADA et al., 2004) and the rootstock used. Several studies show that the anthocyanins present in the grapes are mainly concentrated in the skin (LAGO-VANZELA et al., 2011; REBELLO et al., 2013). Thus, the values of anthocyanins obtained in the present work are smaller, because it was used the whole berry (skin, pulp and seed) for the analysis, thus, occurred a dilution of the anthocyanin values caused by the pulp.

The average content of total carotenoids, total flavonoids, antioxidant activity and total polyphenols of the 'Niagara Rosada' grape in different rootstocks was $188 \mu \mathrm{g} 100 \mathrm{~g} \mathrm{~g}^{-1}, 3.7 \mathrm{mg} 100$ $\mathrm{g}^{-1}, 5239 \mu \mathrm{g} \mathrm{g}^{-1}$ and $476 \mathrm{mg} 100 \mathrm{~g}^{-1}$, respectively.

The levels of total polyphenols obtained by Soares et al. (2008) in the skins of 'Isabel' and 'Niagara Rosada' cultivars were respectively 219.56

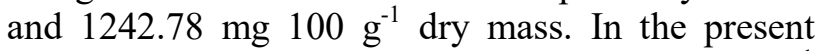
study we obtained from 456.00 to $507.00 \mathrm{mg} 100 \mathrm{~g}^{-1}$ fresh mass for the complete berry of the 'Niagara Rosada' grape. Soares et al. (2008) evaluated the antioxidant efficacy of the skin extracts and obtained the average values of TEAC between 189.82 and $197.00 \mu \mathrm{mol} 100 \mathrm{~g}^{-1}$ by the DPPH 
method and verified the concentration of flavonols

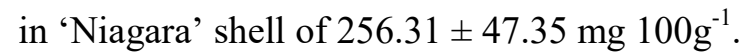

Differing from the results obtained in the present study, Pozzan, Braga and Salibe (2012) verified the effect of different rootstocks on the anthocyanin and total polyphenol content of 'Bordô' grapes. According to these authors, the highest total anthocyanin levels of the 'Bordô' grape were found when the grapes were grafted on the 'IAC 766' rootstock when compared to the '106-8 Mgt' rootstock, however when the total polyphenol contents in grapes skin, the ' $106-8 \mathrm{Mgt}$ ' rootstock provided higher values than those obtained with 'IAC 766'. Also, in 'Bordô' grapes, Mota et al. (2009) verified that the '106-8 Mgt' rootstock promoted increase in the contents of phenolic compounds.

In relation to antioxidant activity, several studies in the literature have reported the difficulty of obtaining similar data in grapes. This makes it
VEDOATO, B. T. F. et al.

difficult to compare the data obtained because of factors such as the use of different analytical methods (DPPH, ABTS, FRAP, ORAC, among others), norms and units of measurement or even due to differences in the reference material of the grape (SILVA et al., 2017). However, it is known that the antioxidant activity of the grapes is correlated with the content of phenolic compounds (BURIN et al., 2014; ROCKENBACH et al., 2011; XU et al., 2010).

Principal component analysis (PCA) was performed on the dataset of the results for the 23 variables analyzed in the 'Niagara Rosada' grape, considering the effect of rootstocks on these characteristics. The Table 5 summarizes the results of the PCA. The total variability of the experiment was explained by four main components, of which the first two were responsible for the explanation of $64.34 \%$ of the variability.

Table 5. Factor loadings, eigenvalues and proportion of variation associated with four principal components (PC) of the PCA

\begin{tabular}{|c|c|c|c|c|}
\hline Traits & PC1 & PC2 & PC3 & PC4 \\
\hline YLD & -0.475 & -0.440 & 0.484 & 0.589 \\
\hline PDT & -0.470 & -0.436 & 0.488 & 0.593 \\
\hline NBP & -0.883 & -0.357 & 0.292 & 0.084 \\
\hline BchM & 0.354 & -0.721 & 0.546 & -0.236 \\
\hline BchL & 0.985 & 0.023 & 0.037 & -0.165 \\
\hline BchW & 0.742 & -0.295 & 0.076 & -0.597 \\
\hline NBB & 0.683 & -0.480 & 0.480 & -0.270 \\
\hline StM & 0.277 & -0.790 & 0.280 & -0.469 \\
\hline StL & -0.115 & 0.816 & -0.567 & 0.018 \\
\hline StW & 0.817 & -0.434 & -0.069 & 0.374 \\
\hline $\mathrm{BrM}$ & -0.784 & -0.302 & 0.084 & -0.536 \\
\hline $\mathrm{BrL}$ & -0.572 & -0.507 & -0.620 & -0.180 \\
\hline $\mathrm{BrW}$ & -0.450 & -0.663 & -0.006 & -0.598 \\
\hline SS & 0.563 & 0.648 & 0.413 & -0.304 \\
\hline $\mathrm{pH}$ & 0.584 & -0.480 & -0.507 & 0.415 \\
\hline TA & 0.945 & -0.299 & 0.038 & 0.128 \\
\hline $\mathrm{SS} / \mathrm{TA}$ & -0.798 & 0.330 & 0.278 & -0.421 \\
\hline $\mathrm{Clr}$ & 0.069 & 0.844 & -0.073 & -0.527 \\
\hline Ant & -0.031 & 0.453 & 0.528 & 0.718 \\
\hline Car & 0.409 & 0.694 & 0.582 & -0.106 \\
\hline Flv & 0.184 & 0.239 & 0.950 & 0.079 \\
\hline $\mathrm{TP}$ & 0.012 & 0.996 & 0.084 & -0.037 \\
\hline AA & -0.495 & 0.062 & 0.842 & -0.203 \\
\hline Eigenvalue & 7.881 & 6.917 & 4.637 & 3.565 \\
\hline Variability $(\%)$ & 34.265 & 30.073 & 20.161 & 15.500 \\
\hline Cumulative $\%$ & 34.265 & 64.339 & 84.500 & 100.000 \\
\hline
\end{tabular}

Trait abbreviation: yield per vine, YLD; productivity, PDT; number of bunches per plant, NBP; bunch mass, BchM; bunch length, BchL; bunch width, BchW; number of berries per bunch, NBB; stem mass, StM; stem length, StL; stem width, StW; berry mass, BrM; berry length, BrL; berry width, BrW; soluble solids, SS; titratable acidity, TA; soluble solids/titratable acidity ratio, SS/TA; chlorophyll, Clr; anthocyanins, Ant; carotenoids, Car; flavonoids, Flv; total polyphenols, TP; and antioxidant activity, AA.

PC1, which explained $34.27 \%$ of the total variation, was effective in separating the rootstocks 'IAC 572' and 'IAC 571-6' from 'IAC 313'. The examination of the PC1 loadings (Figure 2) suggests that this separation is due to width and length of bunches, length of stems and titratable acidity of the 
grapes, which presented high positive loadings. In addition, the number of bunches per plant, the berries mass and the soluble solids/titratable acidity ratio, which in turn presented negative loadings, also contributed strongly. This analysis suggests that the 'IAC 313' rootstock provided for 'Niagara
Rosada', in addition to a larger number of bunches and better ratio. On the other hand, the bunches produced when 'Niagara Rosada' were grafted onto this rootstock were smaller than when using the 'IAC 572' and 'IAC 571-6' rootstocks.

\section{Observations (axes PC1 and PC2: $64.34 \%)$}

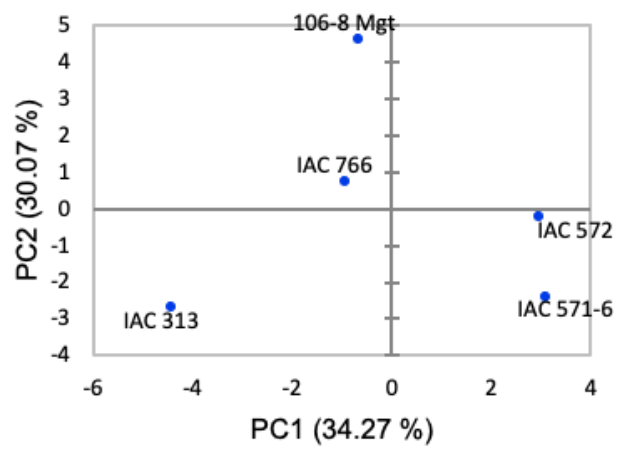

Variables (axes PC1 and PC2:

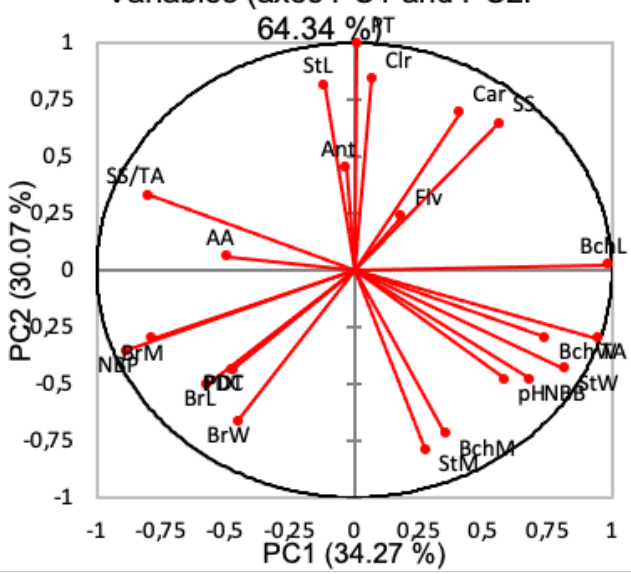

Figure 2. Loadings plot (A) and scores plot (B) of principal component analysis applied to 23 variables analyzed in 'Niagara Rosada' grafted on five rootstocks. Lables of variables are in Table 5.

PC2, which explained $30.07 \%$ of the total variation, was effective to separate the rootstocks '106-8 Mgt' from 'IAC 313' e 'IAC 571-6' (Figure 2). By analyzing scores plot, it is possible to infer that the variables cluster mass, rachis mass and total chlorophyll, carotenoid and polyphenol content contributed the most. PC2 loadings and scores indicate that grapes grafted on '106-8 Mgt' rootstocks tend to have higher phenolic compound contents than when using 'IAC 313' and 'IAC 5716 ' rootstocks. It is possible to infer still that the content of these compounds is negatively correlated with the bunch mass and rachis mass. In all these variables, 'IAC 766' and 'IAC 572' rootstocks provided intermediate values for the 'Niagara Rosada' grape.

\section{CONCLUSIONS}

The rootstocks did not influence the production and physical quality of 'Niagara Rosada' grapes. As for the chemical characteristics, rootstocks only influenced solids content, and 'IAC 766' and '106-8 Mgt' rootstocks promoted higher values of this characteristic. Likewise, the total phenolic compounds and the antioxidant activity of the grapes were not influenced by the studied rootstocks. Therefore, the evaluated rootstocks may be recommended for cv. Niagara Rosada in the region of Jundiaí.

\section{ACKNOWLEDGMENTS}

The authors gratefully acknowledge the financial support of Fundação de Amparo à Pesquisa do Estado de São Paulo (FAPESP) for financial support of this work (process number 2011/03440-6) and for scholarship provided to Conselho Nacional de Desenvolvimento Científico e Tecnológico (CNPq, Brazil) (process number 305724/2018-5) and the Coordination for the Improvement of Higher Education Personnel (CAPES).

RESUMO: Objetivou-se avaliar a influência de porta-enxertos na produção da videira, na qualidade e capacidade antioxidante da uva 'Niagara Rosada' em dois ciclos produtivos. O trabalho foi realizado em Jundiaí-SP, Brasil (26 $06^{\circ} \mathrm{S}, 46^{\circ} 55^{\prime} \mathrm{W}$ e uma altitude média de $\left.745 \mathrm{~m}\right)$. O delineamento experimental foi de blocos causalizados em parcelas subdivididas, as parcelas foram representas pelos porta-enxertos e as subparcelas pelos ciclos de produção, com quatro repetições, constituídas de 6 plantas. Os tratamentos consistiram na combinação entre os porta-enxertos 'IAC 313 Tropical', 'IAC 572 Jales', 'IAC 571-6 Jundiaí', 
'IAC 766 Campinas' e '106-8 Mgt' e a variedade copa 'Niagara Rosada', e os ciclos produtivos de 2013 e 2014. O número de cachos, produção e produtividade das videiras, as características físicas de cachos, bagas e engaços e a composição físico-química do mosto (teor de sólidos solúveis, acidez titulável, pH e relação sólidos solúveis/acidez titulável) foram avaliados nos ciclos de produção de 2013 e 2014. Avaliou-se ainda nas bagas das uvas o conteúdo de clorofilas, antocianinas, carotenoides, flavonoides e compostos fenólicos totais e a atividade antioxidante. Os porta-enxertos não influenciaram a produção e a qualidade física da uva 'Niagara Rosada'. Quanto as características químicas houve efeito dos porta-enxertos apenas no teor de sólidos solúveis, sendo que os porta-enxertos 'IAC 766' e '106-8 Mgt' promoveram maiores valores dessa característica. Da mesma forma, os compostos fenólicos totais e a atividade antioxidante das uvas não foram influenciados pelos porta-enxertos estudados. As videiras, em 2013 apresentaram maior produção e melhores características físicas das uvas, no entanto, o teor de sólidos solúveis nesse ciclo foi inferior ao de 2014.

PALAVRAS-CHAVE: Atividade antioxidante. Compostos fenólicos. Uva para mesa. Vitis labrusca.

\section{REFERENCES}

ABE, L. T. et al. Compostos fenólicos e capacidade antioxidante de cultivares de uvas Vitis labrusca L. e Vitis vinifera L. Ciência e Tecnologia de Alimentos, v. 27, n. 2, p. 394-400, 2007.

ALBACETE, A. et al. Unravelling rootstock x scion interactions to improve food security. Journal of Experimental Botany, v. 66, n. 8, p. 2211-2226, 2015.

ALVARENGA, A. A. et al. Influência do porta-enxerto sobre o crescimento e produção da cultivar de videira Niagara Rosada (Vitis labrusca L. x Vitis vinifera L.), em condições de solo ácido. Ciência e Agrotecnologia, Edição Especial, p. 1459-1464, 2002.

BRAND-WILLIAMS, W.; CUVELIER, M. E.; BERSET, C. Use of a free radical method to evaluate antioxidant activity. Lebensmittel-Wissenschaft Und-Technologie, v. 28, n. 1, p. 25-30, 1995.

BRASIL, 2018. Complementação dos Padrões de Identidade e Qualidade do Vinho e Derivados da Uva e do Vinho. Instrução Normativa ${ }^{\circ} 14$ de 8 de fevereiro de 2018. Ministério da Agricultura, Pecuária e Abastecimento. Diário Oficial da União, Brasília.

BURIN, V. M. et al. Bioactive compounds and antioxidant activity of Vitis vinifera and Vitis labrusca grapes: Evaluation of different extraction methods. Microchemical Journal, v. 114, p. 155-163, 2014.

DÁVALOS, A.; LASUNCIÓN, M. A. Health promoting effects of wine phenolics. In: MORENO-ARRIBAS, M. V.; POLO, M. C. (Eds.), Wine Chemistry and Biochemistry. Springer, New York, pp. 571-591, 2009.

DESOUKY, I. M. et al. Salinity Tolerance of some grapevine cultivars as affected salt creek and Freedom rootstocks. Middle East Journal of Agriculture Research, v. 4, n. 1, p. 112-122, 2015.

DIAS, F. A. N. et al. Videira 'Syrah' sobre diferentes porta-enxertos em ciclo de inverno no sul de Minas Gerais. Pesquisa Agropecuaria Brasileira, v. 47, n. 2, p. 208-215, 2012.

DOWNEY, M. O.; HARVEY, J. S.; ROBINSON, S. P. The effect of bunch shading on berry development and flavonoid accumulation in Shiraz grapes. Australian Journal of Grape and Wine Research, v. 10, p. 55-73, 2004.

EMBRAPA (1999) Sistema brasileiro de classificação do solo. Brasília: Embrapa produção de Informação. Rio de Janeiro: Embrapa Solo, 1999. p. 42. 
IBACACHE, A.; ALBORNOZ, F.; ZURITA-SILVA, A. Yield responses in Flame seedless, Thompson seedless and Red Globe table grape cultivars are differentially modified by rootstocks under semi arid conditions. Scientia Horticulturae, v. 204, p. 25-32, 2016.

JIN, Z. X. et al. Modifications of 'Summer Black'grape berry quality as affected by the different rootstocks. Scientia Horticulturae, v. 210, p. 130-137, 2016.

KAMFFER, Z.; BRINDON, K. A.; OBERHOLSTER, A. Optimization of a method for the extraction and quantification of carotenoids and chlorophylls during ripening in grape berries (Vitis vinifera cv. Merlot). Journal of Agricultural and Food Chemistry, v. 58, p. 6578-6586, 2010.

LAGO-VANZELA, E. S. et al. Phenolic composition of the edible parts (flesh and skin) of Bordô grape (Vitis labrusca) using HPLC-DAD-ESI-MS/MS. Journal of Agricultural and Food Chemistry, v. 59, n. 24, p. 13136-13146, 2011.

LEE, J.; STEENWERTH, K. L. 'Cabernet Sauvignon' grape anthocyanin increased by soil conservation practices. Scientia Horticulturae, v. 159, p. 128-133, 2013.

MAIA, J. D. G.; CAMARGO, U. A. O cultivo da videira Niágara no Brasil. Brasília, DF: Embrapa: Empresa Brasileira de Pesquisa Agropecuária, ed. 1, 2012.

MARGUERIT, E. et al. Rootstock control of scion transpiration and its acclimation to water deficit are controlled by different genes. New Phytologist, n. 194, p. 416-429, 2012.

MOTA, R. V. et al. Produtividade e composição físico-química de bagas de cultivares de uva em distintos porta-enxertos. Pesquisa Agropecuária Brasileira, v. 44, n. 6, p. 576-582, 2009.

MUÑOZ-ESPADA, A. C. et al. Anthocyanin quantification and radical scavening capacity of concord, norton, and marechal foch grapes and wines. Journal of Agricultural and Food Chemistry, v. 52, p. 6779-6786, 2004.

PAULETTO, D. et al. Efeito do porta-enxerto na qualidade do cacho da videira 'Niagara Rosada'. Pesquisa Agropecuária Brasileira, Brasília, v. 36, n. 7, p. 935-939, 2001.

POPOVA, M. et al. Validated methods for the quantification of biologically active constituents of poplar-type propolis. Phytochemical Analysis, v. 15, p. 235-240, 2004.

POZZAN, M. S. V.; BRAGA, G. C.; SALIBE, A. B. Teores de antocianinas, fenóis totais, taninos e ácido ascórbico em uva 'Bordô' sobre diferentes porta-enxertos. Revista Ceres, v. 59, n. 5, p. 701-708, 2012.

REBELLO, L. P. G. et al. Phenolic composition of berry parts of hybrid grape cultivar BRS Violeta (BRS Rubea x KIAC 1398-21) using HPLC-DAD-ESI-MS/MS. Food Research International, v. 54, p. 354-366, 2013.

ROCKENBACH, I. I. et al. Phenolic compounds and antioxidant activity of seed and skin extracts of red grape (Vitis vinifera and Vitis labrusca) pomace from Brazilian winemaking. Food Research International, v. 44, n. 4, p. 897-901, 2011.

ROSSETTO, M. R. M. et al. Antioxidant substances and pesticide in parts of beet organic and conventional manure. African Journal of Plant Science, v. 3, p. 245-253, 2009.

SATISHA, J.; RAMTEKE, S. D.; KARIBASAPPA, G. S. Physiological and biochemical characterization of grape rootstocks. South African Journal of Enology and Viticulture, v. 28, p. 163-168, 2007. 
SILVA, M. J. R. et al. Grape juices produced from new hybrid varieties grown on Brazilian rootstocks Bioactive compounds, organic acids and antioxidant capacity. Food Chemistry, v. 289, p. 714-722, 2019.

SILVA, M. J. R. et al. Phenolic compounds and antioxidant activity of red and white grapes on different rootstocks. African Journal of Biotechnology, v. 16, n. 13, p. 664-671, 2017.

SIMS, D. A.; GAMON, J. A. Relationships between leaf pigment content and spectral reflectance across a wide range of species, leaf structures and developmental stages. Remote Sensing of Environment, v. 81, p. 337$354,2002$.

SINGLETON, V. L.; ROSSI JUNIOR, J. A. Colorimetry of total phenolics with phosphomolybidicphosphotungstic acid reagents. American Journal of Enology and Viticulticulture, v. 16, p. 144-158, 1965.

SOARES, M. et al. Compostos fenólicos e atividade antioxidante da casca de uvas Niagara e Isabel. Revista Brasileira de Fruticultura, v. 30, n. 1, p. 059-064, 2008.

SOUSA, J. S. I.; MARTINS, F. P. Viticultura Brasileira: Principais variedades e suas características. Piracicaba: FEALQ, 2002. 368 p.

TECCHIO, M. A. et al. Extração de nutrientes pela videira 'Niagara Rosada' enxertada em diferentes portaenxertos. Revista Brasileira de Fruticultura, v. 33, p. 736-742, 2011.

TECCHIO, M. A. et al. Influence of rootstocks and pruning times on yield and on nutrient content and extraction in 'Niagara Rosada' grapevine. Pesquisa Agropecuária Brasileira, v. 49, n. 5, p. 340-348, 2014.

TERRA, M. M. et al. Produtividade da cultivar de uva de mesa Niagara Rosada sobre diferentes porta-enxertos, em Monte Alegre do Sul, SP. Revista Brasileira de Fruticultura, v. 25, n. 3, p. 549-551, 2003.

VERDI, A. R. et al. Panorama da vitivinicultura paulista: censo de 2009. Informações Econômicas, São Paulo, v. 41, n. 11, 2011.

VOLP, A. C. P.; RENHE, I. R. T.; STRINGUETA, P. C. Pigmentos naturais bioativos. Alimentos e Nutrição, v. 20, n. 1, p. $157-166,2009$.

XU, C. et al. Phenolic compounds and antioxidant properties of different grape cultivars grown in China. Food Chemistry, v. 119, n. 4, p. 1557-1565, 2010. 